\title{
Competency Development of Civil State Apparatus in Term of Human Resource Management
}

\author{
Sintha Wahjusaputri, Somariah Fitriani \\ Departement of Educational Administration \\ University of Muhammadiyah Prof. DR. HAMKA \\ Jakarta, Indonesia \\ sinthaw@uhamka.ac.id
}

\begin{abstract}
The reform of public management will in turn affect the demands of qualifications or competence of Human Resources within the government institutions. In this case, the human resource development of civil servants in the public sector must be directed to the arrangement of competence in accordance with the field of duty in the present and in the future. The phenomena occurring in the development of civil state apparatus competence in building the human capital are: (1) the competence development is considered as a burden; (2) the competence development is considered as an asset; (3) the competence development becomes the part of organizational strategy; (4) the competence development is the core of Talent Management along with recruitment and retention. Hopefully, professional civil state apparatus who are able to encourage and support the pace of government development can be realized. To be inferred that the competence development of civil state apparatus is required to be executed by prioritizing the awareness, commitment, communication and coordination among the stakeholders, particularly in planning the program of competence development for civil state apparatus.
\end{abstract}

Keywords-Competency-Based Human Resource Management, Human Capital, and Civil State Apparatus

\section{INTRODUCTION}

Discussion on the portrait of today's civil state apparatus in Indonesia often revolves around the discourse of poor professionalism, level of inadequate well-being, non-ideal distribution and composition, incompetence -based placement position, subjective performance assessment, non-job performance-based promotion, low work culture and work ethos as well as inconsistent application of disciplinary rules as internal issues. The issue of civil state apparatus (CSA) can be viewed from three perspectives: the perspectives of the system (laws and policies), institutional and human resources. From the perspective of the legislation, many laws and regulations that have set up its management are considered to be out of date. Subsequently, it is no longer compatible with the demands of today's global environment. Although the Law No. 43 of 1999 has amended the Law No. 8 of 1974 on the Principles of Civil Service, the majority of regulation implementation has not adapted to the demands and the times. The Efforts to renew the regulation has already begun even though the significant results have not shown yet.

From the institutional perspective, there are several agencies dealing with CSA policy formulation such as the Ministry of Empowerment of State Apparatus, Institute of
Public Administration, the State Personnel Board, and Coordinating Minister of Politics, Law and Security; and the Department of Home Affairs. In general, it can be said that the absence of a firm regarding the division of authority ASN among some central government agencies led to a policy issued by an institution that often overlap with the policies issued by the other agencies. From the Human Resources perspective, the data collected from 2015 until today are: the total number of CSAs in Indonesia is 4,475,315 (21.04\% in the central city and $78.96 \%$ in the regional cities). The average annual growth of CSA from $2010-2015$ is $-0.312 \%$ and the percentage of the labor force is 118.19 million $(3.89 \%)$. The number of CSA based on the group of age, gender, and education level is elaborated shown in Fig. 1.

Challenges to the professionalism of the State apparatus is currently as follows, their chances of misuse of authority/ power which would disadvantage the state and society, legal mafia, global competition are increasingly complex, and various kinds of the other crucial issues. At this time, Effendi [1] stated that to realize the state apparatus that can be justified, the reforms of officials should be carried out continuously, and sustained by the motivation to seek a more effective and efficient aspect. The professionalism of the Civil Service is the fulfillment of fit between the capability of personnel and the task requirements as the formation of the professional apparatus. The expertise and capacity of the reflecting direction and objectives are achieved by an organization. Tangkilisan [2] said that when an organization strives to provide an excellent public service, the professionalism of the organization based on the objectives must be achieved.

This study is expected to formulate and design a rational and integrated State Civil Apparatus management system from the planning, which needs to have termination/retirement. Through this study, it is also expected to discover a more comprehensive portrait of the problems and the reasons why the management system applied during this time cannot be run effectively. Therefore, the issue is viewed from the design of legislation and empirical conditions in the field. The finding is expected to provide a direction for further formulation of policy alternatives from management system reform in the future.

The various problems, as noted above, are not far from the reality or empirical experience in the field at this time. This case is reflected in the performance of appraisal system that is 

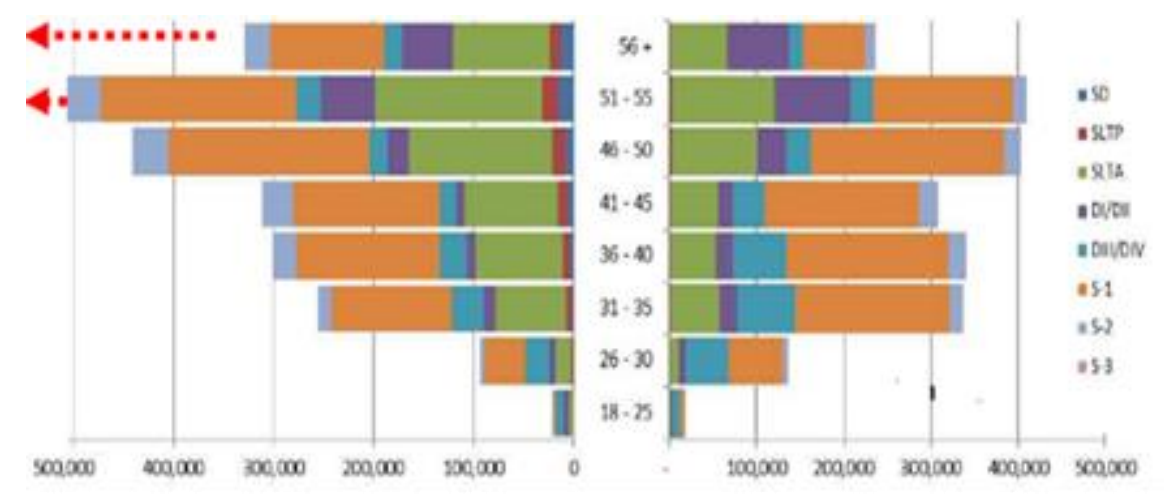

Fig. 1. Profile of CSA in Indonesia Source: Ministry of Empowerment of State Apparatus, 2015

still highly flavored with the formal approaches leading to less describe the existing objective conditions. Similarly, the appointment of the position is not really based on the real competence of the appointed candidates, as well as education and training systems as the part of a career development system. In terms of the award (reward and punishment), it is also not implemented in line with the expectations and justice. The scope of this study concerns on the management aspects of the state apparatus in Indonesian civil regarding the system, institutional and human resources. The study focuses on finding the issues of the causes of unprofessional apparatus of civil state in Indonesia despite the fact that various attempts have been made such as the changes in legislation, institutional arrangements in charge of personnel, the changes in the approach to education and training and the other policies that lead to improve the performance and competence of civil servants.

To answer the challenge, the necessary changes come about through the bureaucratic reform. Keban [3] said that the management system of State Civil Apparatus has a number of fundamental weaknesses, among others: (1) it highlights more the administrative aspect than management aspect, especially the modern resource management; (2) it tends to be centralized so that it lacks to accommodate the values of efficiency and effectiveness in achieving the organizational objectives of each institution both at central and regional levels; (3) there is no principle of check and balance in the delivery of personnel management that encourages the duplication both at the central and district areas that ultimately hinders the principle of accountability; (4) it is less supported by the adequate personnel information system, as a result it gives a negative influence on the decision making process in the personnel management; (5) it cannot control and apply the principles of the merit system explicitly; (6) it has no legal basis for noncareer official appointments; (7) it does not well accommodate the classification of occupations and competence standards that negatively affects the organizational performance and individual achievement; (8) the existence of the State Personnel Commission is less independent and its position is not welldefined.

Law no 5 of 2014, on the State Civil Apparatus, is expected to improve the management of government - oriented public services because CSA is no longer oriented to serve his boss, but the community. This rule puts the CSA as a profession that is free from the political interference and implements an open career system that promotes the principles of professionalism. The principles must have the competence, qualifications, performance, transparency, objectivity, and be free from the corruption based on the human resource management. Additionally, the principles must put forward the merit system towards the realization of professional government bureaucracy. CSA as servants of the state must carry out the tasks mandated by the state to them and as a public servant; CSA is essentially obliged to serve the community instead of being served by the public. So, the mind-set of bureaucrats is expected can be changed from being serviced to serve. In doing the public service, the work must build a common vision and commitment and understand the spirit of professionalism. The professionalism of government officials becomes one of the important issues in the implementation of the government. Great authority owned by the government would only benefit the wider community if it is followed by improving the professional ability of its agents.

A competence needs to get serious attention to determine the achievement of organizational goal, which in this sense, it is a way of describing how well (or not) your firm performs its necessary activities. Competence as the personal aspects includes the nature, motives, value systems, attitudes, knowledge, and skills. Jones [4] argued that one of the core competences as 'the collective learning in the organization, especially how to co-ordinate the diverse production skills and integrate the multiple streams and technologies'. The human elements of the organization are capable of learning, changing, innovating and providing the creative thrust which if it is properly motivated, it can ensure the long-term survival of the organization. The vital role of the social capital plays at both the individual and organizational levels in terms of creating value and stimulating the new knowledge and innovation. Human capital investments involve an initial cost where the individual or firm hopes to gain a return in the future. To improve the performance of the local government, the factors of human capacity development are very urgent. In addition, responding to the high demand of the people of the local government performance, the capacity development (capacity building) of Human resource is a central factor in the organization. The human resource, as "Strategic Human Resource Management, is the linking of Human Resource Management with strategic role and objectives to improve the business performance and develop the organizational cultures 
and foster the innovation and flexibility" [5]. The strategic role in managing the human resources is able to elaborate all the resources owned by each employee, and the ability of human resource is a competitive advantage for the organization. It is important to note that this study provides an overall picture of the professionalism of Indonesia seen from a number of criteria such as competence, accountability apparatus, and loyalty to the ability of the apparatus.

\section{RESEARCH METHODOLOGY}

This study employed a qualitative approach, which attempted to find answers of: 1) why is civilian personnel management system for a country not able to create a professional state apparatus and civil competence, work ethos and morality?; 2) What does actually become the root cause of problems concerning the performance of the apparatus of the state civil?; 3) do the main problems lie on the management functions of the apparatus of civil countries such as planning, procurement, promotion/transfer, development, payroll, patterns of careers, rights and obligations; and the need for training as a system management apparatus state civil or lie on the other factors? Judging from the goal, the study is included in applied research since the results are expected to be used for solving the empirical problems in implementing the coaching of the civilian state apparatus to become more effective in the future [6].

\section{RESULTS AND DISCUSSION}

\section{A. Civil State Apparatus}

Based on the results of the performance appraisal, the interview conducted by CSA was oriented to increase the work performance and development potential of CSA. In government regulation, an official appraiser, as the direct supervisor of the CSA concerned with the provisions of the lower echelon $\mathrm{V}$ or other official specified, is authorized to make a performance appraisal. The purpose of performance appraisal is to ensure the objectivity of coaching CSA conducted based on the systems work performance and career, system that places the emphasis on the system performance. Performance appraisal is a process that begins with a series of performance management of all planning work performance such as target employee work, benchmarking covering the aspects of quantity, quality, time, and cost of each activity of office tasks.

Performance appraisal is used to increase the organizational performance through the improved work performance, development potential, and career concerned and management development, organization, and work environment. The head of an official appraiser functionally does not merely give a legal assessment from the official appraiser, but rather serves as a motivator and evaluator of how effective the official appraiser to assess, to compensate for the assessment and perception of assessors officials in an effort to eliminate the biases assessment. Mangkunagara [7] defines job performance is the result of the quality and quantity of a work accomplished by an employee in performing their duties in accordance with the responsibilities given. Job performance is a result of a person's work achieved by carrying out the tasks assigned to them based on skills, experience, sincerity and time.

\section{B. Competence}

Act No.43 of 1999 on the Amendment of Act No. 8 of 1974 about the Fundamentals of Civil Servants Article 17 paragraph 2 states that the appointment of Civil servants in a position is conducted based on the principles of the professional competences, and the achievements on the job performance. The Regulation of the Chief of the State Personnel Board No. 7 of 2013 states that the competences of the apparatus include the capabilities of thinking, Self-and-other people and task Managing. In the context of the implementation of the administrative system of the Government of the Republic of Indonesia, the competences of the state apparatus are classified into four types, namely (Joko. 2003):(1) Technical competence; (2) managerial competence; (3) Social Competence; and (4) Intellectual/strategic competence.

There are several challenges in improving the competences of the government officials such as the selection process held by the central government apparatus and the lower budget for competence development of the apparatus. The recruitment system of the Indonesian government officials is performed by the central government leading to some disadvantages including: a lack of flexibility in meeting the needs of officers, no guarantee on the quality or quantity to correspond to the needs of the regional government, and less attention given to the scale of priority to fit the needs. All of these results in some difficulties in placing the apparatus to implement the principles of the right man and the right place. P. W. Kennedy and S. G. Dresser [8] defined competencies as anything employees have or acquire that contribute to the organizational success. Spencer [9] defined competency as a characteristic that underlies a successful performance. Employee competencies are characteristics associated with a successful performance. These characteristics should manifest themselves in observable behavioral patterns that make a positive difference. Every employee is definitely required to have a certain competence on the job or position he does.

According to Spencer and Spencer [9], there are five characteristics of competence: 1) motive, namely something that someone constantly thinks of or desires, which leads, urges, or causes them to take a certain action; 2) nature, referring to innate physical traits and consistent responses to the various situations or information; 3) individual perception: a person's attitude, values, or depiction of their own self; 4) knowledge and ability, the characteristic of competence referring to the information owned by someone which is relevant to a certain job, and 5) skills, or the capacity to undertake certain mental or physical tasks. Dwiyanto [10] defined bureaucrat competence as the accumulation of several sub-variables, such as education level, years of work experience, and variations of training received. Theoretically, an individual or officer in a public organization is highly competent, capable of undertaking their role and function at maximum capacity, and in turn will improve the organization efficiency in reaching its set goals and objectives. Consequently, the efforts to improve the competence of officers in every organization are strategic moves that should 
be conducted continuously. Among the several definitions above, there is one common thread asserting that competence is a behavior that can be observed and measured. Behavior can be observed and manifested in the form of knowledge, skills, and experience. The concept of human resource competence development of civil state apparatus is as follows: (1) The technical competence is based on the level and specialization of education, functional technical training, and technical working experience; (2) The managerial competence is based on the level of education, structural training or management, and leadership experience; (3) The cultural social competence is based on the work experience related to the plural society in terms of religion, ethnicity, and culture as to have a national vision. The competence development is the basis for career development and becomes one of the bases for the removal of Job. Needs and competency development plan consists of: (a) an inventory of types of competencies that need to be improved from every civil state apparatus; and (b) an implementation plan competence development. Competence development is a plan carried out for a period of one year-work plan financing contained in the annual budget of the Government Agencies. To plan the competence development, the gap analysis of competency and performance needs to be conducted. The competency gap analysis is done by comparing the competency profile of each civil state apparatus. Meanwhile, the performance gap analysis is done by comparing the results of performance evaluation and performance targets of occupied positions. The committee sets out the needs and competency development. The needs and competency development plan is set out by the committee for competence development. The needs and competency development plan includes: (a) the development of the type of competencies; (b) the development of the target of civil state apparatus competence; (c) the type and competency development path; (d) the organizer of the competence development; (e) a schedule or time of execution; (f) the conformity of the competence development with the curriculum standards; and $(\mathrm{g})$ the required budget. The needs and competency development plan is put into the information system of State Administration Institution. The competence development plan is submitted to the State Administration Institution as materials for national competency development plan. National competency development plan is established by the Minister and published in the information system training, which is integrated with civil state apparatus Information System. The implementation of the competency development must be in accordance with a predetermined plan. The competency development can be implemented in the form of: (a) education; and/or (b) training.

The results of this study were in line with the previous research conducted by [11]-[13] who explained that competence affects the performance of employees. Performance and effectiveness of employees in performing the task is determined by the competencies required by the field of work. Through the more adequate competence, employees will be more mastered and able to practically apply all job tasks in accordance with the job description set. It implies that to improve the performance, someone must improve his/her competence. The high competencies possessed by the employees in an organization or company definitely affect the performance that will ultimately determine the competitive quality of the company itself. To achieve the purpose of the agency in solving the existing environmental and transportation problems, the civil servant should have the appropriate competence maximally.

\section{Human Capital Management}

Research objects are the central government institutions of which duties and responsibilities are to manage the civil servant or now it is well known as government human capital in Indonesia. Their duties are planning, selecting and requiring, developing and training, engaging, and retaining the process of government human capital. Achieving good governance calls for new set of capabilities so that the public managers can take proactive steps in making decisions, designing implementation strategies, determining priorities and allocating resources to respond the citizens' demands. Human capital development is a fundamental pre-requisite. The influence of political economy on resource use, institutional inability, lack of a long-term national development strategy, and weak political leadership have distorted the human capital development initiatives and their use [14]. The realization and enhancement of good governance is a major challenge to the medium- to long-term stability and sound economic development of South Asia [15]. Claudia Goldin [16] defined human capital as the stock of skills that the labour force possesses. The flow of these skills is forthcoming when the return to investment exceeds the cost (both direct and indirect). K. Kwon and D. E. Rupp [17] defined the first is to utilize human as labour force ee related to economic added-value that is generated by the input of labour force as the other production factors such as financial capital, land, machinery, and labour hours. Another thing is that the human capital can be viewed as the target of investment through education and training. The second, the human capital expansively includes the meaning of "human as creator" who frames knowledge, skills, competency, and experience originated by continuously connecting between "self" and "environment". At the same time, the national effort is required to use the human capital effectively in countries like Bangladesh, which must meet the rapidly changing educational needs of their people if they want to be a part of the recent economic growth that is occurring in Asia and global world [18], [19]. Thomas et al [20], defined Human Capital as the 'people, their performance and their potential in the organization'. The inclusion of the term 'potential' is important as it indicates that employees can develop their skill and abilities over time.

The role of human capital in strengthening the institutional capacity has two aspects. The first one is a resource base of knowledge and skill and the second one is the ability to utilize as well as improvise this resource for fulfilling public service mandates. Utilization of human capital can be defined as 'the degree of match or congruence between an individual's skills and the opportunity to use these skills in that individual's work role' [21]. An important element in the understanding of the utilization of human capital is that in many institutions of the developing world, it is not the lack of skills and capabilities that becomes the problem, but the absence of the appropriate mechanisms to utilize them. Yahya [21] argued that without effective utilization schemes, investment in human resource 
development programs will do a little to improve the organizational performance or increase the legitimacy of the governance system. Therefore, if the human capital resources are not properly utilized, the desired effect of their accumulation may not be a fruitful one. Under these circumstances, organizations have to compromise between effectiveness and productivity. Chatzkel [22] argued that the knowledge-based enterprise can encourage the entrepreneurship and new human capital.

\section{CONCLUSION}

Based on the above discussion, it can be concluded that the issues of the civil service management system is extremely complex and present in all chains of the civil state apparatus development, either on the system/legislation, institutional or human resources. Many laws and regulations are no longer relevant to the demands of current conditions such as the lack of synchronization between the Act and the implementation of the regulations under it, and the lack of synchronization between the sub-systems in the overall management as the career pattern of the performance measurement as well. The overlapping job of authority between the agencies which are responsible for the handling of policy, management, and personnel affairs occurs which tends to be less effective. In addition, there is no coordination between the institutions. In terms of the quality of human resources, the civil state apparatus profile shows the low quality, capacity, and mentality as a result of the low rationality and linkages between the sub-systems in management from planning needs until the dismissal. Such problems are almost never decomposed completely and consequently. Because of such problems, the performance and professionalism of civil servants have always been widely reported. Therefore, to improve the performance, professionalism, and wellbeing of the civil state apparatus, the civil service management system as a whole and the integrated system has come to reform. Hence, the proposed reform approach must be integrated and comprehensively follow the steps as suggested.

The renewal of the civil state apparatus management is urgently required since it has not been effective, rational, and healthy. Therefore, within the framework of the civil state apparatus management reform, several things are recommended including:(1) Civilian personnel management reform policies are aimed at creating a state apparatus management system of effective civil and rational state as to establish the figure of civilian professional state apparatus to have a high-performance, good welfare, and virtuous life; (2) Evaluating the substance of the legislation comprehensively and in detailed starting from the Law no. 43 of 1999 on the Regulation Government, Presidential Decree, Decree of the Minister of Home Affairs, Decision and Circular Letter of State Minister of State Apparatus Empowerment, Decision and Circular Letter of Head of State Personnel, Decision and Letter Circular Head of State Administration Institution and others; (3) Reorganizing the authority in the field of personnel between the relevant agencies such as the Ministry of Administrative Reform, Ministry of Home Affairs, State Personnel Agency, State Administration Institution; (4) Reforming and updating the management system of coaching civil state apparatus according to the following stages: (a) preparation of roadmap; (b) setup of legislation in the field of personnel; (c) socialization; (d) initiation; (e) internalization; and (f) stabilization; (5) Regarding the human resources, a systematic effort is consistently required to build the capacity of civil servants who have professionalism, good performance, and competence.

To achieve such thing, the steps that should be taken are: (1) redesigning the civil state apparatus coaching management system based on the review of the legislation. This renewed guidance management system puts forward the application of merit system by integrating the subcontinent and rationalsystematic personnel management sub-systems; (2) conducting the recruitment of civil state apparatuses selectively with the higher passing standards to obtain a more qualified civil state apparatus. However, during the introduction of this reform, it is advisable that the recruitment of the state civil apparatus is temporarily suspended; and (3) enforcing the strict and consistent personnel rules. The civil servant development method needs to be focused on the guidance that supports the successful completion of the main tasks.

\section{REFERENCE}

[1] T. Effendi, "Pembangunan Sumber Daya Manusia Aparatur Negara," 2008.

[2] H. N. S. Tangkilisan, Manajemen publik. jakarta: Gramedia Widia Sarana Indonesia, 2005.

[3] Y. T. Keban, "Pokok-Pokok Pikiran Perbaikan Sistem Manajemen SDM PNS di Indonesia.," J. Kebijak. dan Adm. Publik, vol. 8, no. 2, pp. 1532, 2004.

[4] G. R. Jones and G. R. Jones, Organizational theory, design, and change. Pearson International Edition, 2010.

[5] G. Dessler, Human Resource Management, 10 th Edition. Boston: Pearson, 2000.

[6] A. Arikunto, Metodologi Penelitian. jakarta: Rajawali Press, 2009.

[7] M. Mangkunegara and P. Anwar, Manajemen Sumber Daya Manusia. Bandung: PT. Remaja Rosda Karya, 2002.

[8] P. W. Kennedy and S. G. Dresser, "Creating a competency-based workplace. Benefits and Compensation Digest," vol. 42, no. 2, pp. 20 23, 2005.

[9] L. . Spencer and S. M. Spencer, Competence at Work. New York: John Willey \& Sons, 1993.

[10] A. Dwiyanto, R. Partini, B. Wicaksono, W. Tamtiari, B. Kusumasari, and M. Nuh, Reformasi Birokrasi Publik di Indonesia. diterbitkan Pusat Studi Kependudukan dan Kebijakan UGM, vol. 2002. Yogyakarta: Galang Printika.

[11] H. Zaim, M. F. Yasar, and O. F. Unal, "Analyzing The Effects Of Individual Competencies On Performance: A Field Study In Services Industries In Turkey," J. Glob. Strateg. Manag., vol. 7, no. 2, pp. 67-77, 2013.

[12] C. J. Liang, Y. L. Lin, and H. F. Huang, "Effect of core competence on organizational performance in an airport shopping center," J. Air Transp. Manag., vol. 31, pp. 23-26, 2013.

[13] A. Lotunani, M. S. Idrus, E. Afnan, and M. Setiawan, "The Effect of Competence on Commitment, Performance and Satisfaction with Reward as a Moderating Variable," Int. J. Bus. Manag. Invent., vol. 3, no. 2, pp. 18-25, 2014.

[14] R. Samaratunge, Q. Alam, and J. Teicher, "The new public management reforms in Asia: A comparison of South and Southeast Asian countries," Int. Rev. Adm. Sci., vol. 74, no. 1, pp. 25-46, 2008.

[15] R. Samaratunge, K. Coghill, and H. M. A. Herath, "Tsunami engulfs Sri Lankan governance," Int. Rev. Adm. Sci., vol. 74, no. 4, pp. 677-702, 2008 . 
[16] C. Diebolt, M. Haupert, and C. Goldin, "Human Capital," Handb. Cliometrics, pp. 1-40, 2014.

[17] K. Kwon and D. E. Rupp, "High-performer turnover and firm performance: The moderating role of human capital investment and firm reputation," J. Organ. Behav., vol. 34, no. 1, pp. 129-150, 2013.

[18] Q. R. Alam, S. Samaratunge, N. As-Saber, C. Nyland., and H. D. Cieri, "Globalisation and Labour Mobility in Developing Countries," in Australian and New Zealand Academy of International Business (ANZIBA) annual conference., 2005.

[19] Q. Alam and K. Hossain, "Impact of Corruption on Foreign Direct Investments in Developing Countries: a case study of Bangladesh," in Asia Pacific Researchers in Organisation Studies, 2005.

[20] H. Thomas, R. R. Smith, and F. Diez, Human capital and global business strategy. Cambridge University Press., 2013.

[21] K. O. Al-Yahya, "The Over-Educated, Under-Utilized Worker: Why Doesn't Human Capital Development Bring Desired Outcomes?," Acad. Manag., vol. 2007, no. 1, pp. 1-6, 2007.

[22] J. L. Chatzkel, Knowledge capital: How knowledge-based enterprises really get built. Oxford University Press., 2003. 